\title{
Skyscapes Beyond the Horizon
}

Regardless of how any specific scholar defines archaeoastronomy, the field has historically focused on structural alignments to horizon events: megalithic passage graves, stone circles, Mayan temples, Egyptian pyramids and other monumental constructions have been surveyed for possible alignments with the rising or setting of the Sun, Moon, stars and planets (e.g. the many case studies in Ruggles 2015). "Horizon astronomy", the informal term used to describe the motions of the rise and set positions of the celestial objects, has become an essential component in the training of an archaeoastronomer (e.g. Magli 2015, 3-28; Ruggles 2015, 459-482), often to the detriment of a more holistic understanding of celestial dynamics (see, for example, the arguments raised by Brady 2015 and Sims 2016). However, horizon alignments are but one form of engagement with the skyscape, and the ethnographic and historical records suggest a multiplicity of other forms. Examples are too numerous to cover fully, but it is important to investigate at least some of the most ubiquitous.

The stars are more than mere dots in the sky: whether in isolation or connected to form asterisms and constellations, they can represent people, animals and other elements of a culture's environment and play out stories, myths and legends in the sky, whether over a single night or through the seasons (Frank 2015). Not all stars touch the horizon: some are visible every night, all night long and rotating around the celestial pole, making them particularly useful for night-time navigation (Pimenta 2015). Other cultures create dark cloud constellations, looking not at the bright dots, but the dark spaces between them (Urton 1981). In perfectly dark skies it is impossible not to be awed by the Milky Way. Depending on one's location, time of night and season, the Milky Way can appear either vertically upright or horizontal just above the horizon. Its motions are more complicated than those of the other celestial objects, but ethnographic records are full of mentions of the Milky Way and its role (e.g. Lévi-Strauss 1970; 1978).

For cultures inhabiting regions between the Tropics of Cancer and Capricorn, at some point(s) in the year, the Sun will be directly overhead - at the zenith. During these moments of zenith Sun all shadows merge with the object that creates them, something that did not go unnoticed and may have been seen as significant (see e.g. Malville et al. 1998). Some cultures have gone to the trouble of marking the horizon position of sunrise for such days, making it a predictable event (Aveni and Hartung 1981), but the zenith Sun experience occurs only when the Sun is at its furthest point from the horizon. 
Graphical representations of celestial objects or events, whether realistic or symbolic, are also attested in many societies' historical and ethnographic records (e.g. Pásztor and Roslund 2007; Murray 2015). Symbolic representations are usually more difficult to discern and, it must be noted, they might appear not only in art, but also in other forms of materiality, for example architecture (e.g. Hugh-Jones 1995; Campion 2015), or even in portable artefacts that might have been sympathetically associated with the skyscapes (e.g. Wainwright 1932).

Finally, myth, folktales and ritual are perhaps at the highest rungs of Hawkes' ladder of inference and, as such, are the least accessible in archaeological contexts (Hawkes 1954). Anthropologists have recorded examples for hundreds of different cultures, and the sky usually plays a role in them (e.g. Lévi-Strauss 1970; 1978; Hayden and Villeneuve 2011; Frank 2004). The challenge that faces the skyscape archaeologist is whether and how to use the archaeological record to infer such immaterial, but nonetheless important, cultural elements.

This brief list of different ways in which societies engage and express this involvement with the sky is not complete - nor could any be - but although not all forms of engagement will find their way into the archaeological records of long-lost societies, some will. Of these, each presents, collectively or individually, its own challenges to the modern scholar who tries to unravel them. For example, it is easy to fall prey to anachronism when it comes to symbolism, as imagery similar to modern Western depictions of celestial objects have been interpreted as such, often without any culturally contextualised supporting evidence (as noted, for example, by Krupp 2015).

To illustrate, highlight and promote further research on such topics, JSA has invited scholars in this field to present their views on non-alignment forms of engagement with the skyscape and their material manifestations. We are delighted that Ivan Šprajc, Brian Hayden, Roslyn M. Frank and Bernadette Brady have agreed to meet the challenge, and their opinions are printed below.

\section{References}

Aveni, A. F. and H. Hartung, 1981. "The Observation of the Sun at the Time of Passage through the Zenith in Mesoamerica". Journal for the History for Astronomy 12: S51-S70.

Brady, B., 2015. "Star Phases: The Naked-Eye Astronomy of the Old Kingdom Pyramid Texts". In Skyscapes: The Role and Importance of the Sky in Archaeology, edited by F. Silva and N. Campion, 76-86. Oxford: Oxbow Books.

Campion, N., 2015. "Religion, Archaeology and Modern Calendar Buildings: A Study of Avon Tyrrell House in England". Journal for the Academic Study of Religion 28 (2): 176-190. https://doi.org/10.1558/jasr. v28i2.26624

Frank, R. M., 2004. "Hunting the European Sky Bears: German Straw-Bears and their Relatives as Transformers". In Symbole der Wandlung - Wandel der Symbole. Proceedings of the Gesellschaft für wissenschaftliche Symbolforschung / Society for the Scientific Study of Symbols, edited by M. Rappenglück and B. Rappenglück, 141-166. Munich: Kassel.

Frank, R. M., 2015. "Origins of the 'Western' Constellations". In The Handbook of Archaeoastronomy and Ethnoastronomy, edited by C. L. N. Ruggles, 147-163. New York: Springer.

Hayden, B. and S. Villeneuve, 2011. "Astronomy in the Upper Palaeolithic?" Cambridge Archaeological Journal 21 (3): 331-355. https://doi.org/10.1017/S0959774311000400

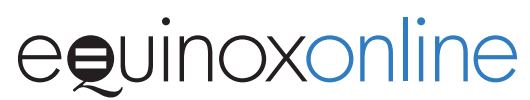


Hawkes, C., 1954. "Archaeological Theory and Method: Some Suggestions from the Old World". American Anthropologist 56 (2): 155-168. https://doi.org/10.1525/aa.1954.56.2.02a00020

Hugh-Jones, S., 1995. "Inside-Out and Back-to-Front: The Maloca and the House in Northwest Amazonia". In About the House: Lévi-Strauss and Beyond, edited by J. Carsten and S. Hugh-Jones, 226-252. Cambridge: Cambridge University Press. https://doi.org/10.1017/CBO9780511607653.011

Krupp, E. C., 2015. "Crab Supernova Rock Art: A Comprehensive, Critical and Definitive Review". Journal of Skyscape Archaeology 1 (2): 167-198. https://doi.org/10.1558/jsa.v1i2.28255

Lévi-Strauss, C., 1970. The Raw and the Cooked. London: Jonathan Cape.

Lévi-Strauss, C., 1978. The Origins of Table Manners. London: Jonathan Cape.

Magli, G., 2015. Archaeoastronomy: The Science of Stars and Stones. New York: Springer.

Malville, J. McKim, F. Wendorf, A. A. Mazar and R. Schild, 1998. "Megaliths and Neolithic Astronomy in Southern Egypt". Nature 392: 488-491.

Murray, W. B., 2015. "Astronomy and Rock Art Studies". In The Handbook of Archaeoastronomy and Ethnoastronomy, edited by C. L. N. Ruggles, 239-250. New York: Springer. https://doi.org/10.1007/978-1-461 4-6141-8_10

Pásztor, E. and C. Roslund, 2007. "An Interpretation of the Nebra Disc". Antiquity 81 (312): 267-278. https:// doi.org/10.1017/S0003598X00095168

Pimenta, F., 2015. "Astronomy and Navigation". In The Handbook of Archaeoastronomy and Ethnoastronomy, edited by C. L. N. Ruggles, 43-63. New York: Springer. https://doi.org/10.1007/978-1-4614-6141-8_7

Ruggles, C. L. N., ed., 2015. Handbook of Archaeoastronomy and Ethnoastronomy. New York: Springer. https:// doi.org/10.1007/978-1-4614-6141-8

Sims, L., 2016. "What is the Minor Standstill of the Moon?" Journal of Skyscape Archaeology 2 (1): 67-76. https:// doi.org/10.1558/jsa.v2i1.30212

Urton, G., 1981. At the Crossroads of the Earth and the Sky: An Andean Cosmology. Austin: University of Texas Press.

Wainwright, G. A., 1932. "Iron in Egypt". Journal of Egyptian Archaeology 18 (1-2): 3-15. https://doi.org/ 10.1177/030751333201800102 